\title{
AS RECENSÕES G E W DA VIDA DE ESOPO
}

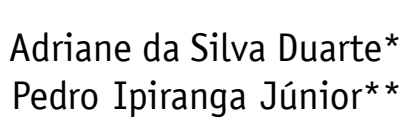

RESUMO: A Vida de Esopo é uma obra que apresenta traços de dois gêneros: gênero biográfico e gênero romanesco antigos. Neste trabalho, expomos, em caráter introdutório, algumas caraterísticas peculiares desse tipo de narrativa e apresentamos uma tradução da parte inicial das duas recensões principais da obra: a recensão $G$ e a recensão $W$.

PALAVRAS-CHAVE: biografia antiga; Vida de Esopo; romance antigo.

\section{THE G AND W RECENSIONS OF THE LIFE OF AESOP}

${ }^{*}$ FFLCH/USP.

asduarte@usp.br

** Universidade Federal do Paraná. junioripiranga7@hotmail. com

\begin{abstract}
The Life of Aesop is a work that shows traces of two genres: the ancient biography and the ancient novel. In this work, we expose, in an introductory way, some peculiar features of this kind of narrative and present a translation of the first part of the two main recensions of the work: the $\mathrm{L}$ recension and $\mathrm{W}$ recension.
\end{abstract}

KEYWORDS: ancient biography; Life of Aesop; ancient novel.

\section{PÉtroi Pétros eû PRÁtTeIN}

$\mathrm{N}$

o multifacetado gênero do bios na Antiguidade, há um corpus de narrativas, que de certa forma, compõem uma espécie de relato biográfico, cuja composição, constituição e transmissão indicam, senão um estatuto romanesco, pelo menos uma influência profunda do gênero romanesco antigo. Esse conjunto de obras tem 
vários traços em comum, em especial, para a finalidade aqui buscada, a interrelação, cruzamento ou mesmo hibridismo dos gêneros do bíos e do romance antigo. A princípio, comporiam esse corpus as seguintes obras: a Vida de Esopo, o Romance de Alexandre, A Vida de Apolônio de Tiana, os cincos primeiros Atos Apócrifos dos Apóstolos e, de certa forma, A Vida do Filósofo Segundo, o silencioso. Ainda poderíamos acrescentar a Vida Herodoteana de Homero e o Certame de Homero e Hesíodo.

Dentro do que é proposto pelo dossiê Bíos, nosso objetivo é meramente expor de modo sumário uma avaliação crítica do Romance de Esopo ou Vida de Esopo, a título de introdução à obra, e oferecer ao público uma tradução da primeira parte do texto das duas recensões mais importantes: a recensão $\mathrm{G}$, cuja tradução é de Adriane Duarte, e a recensão W, cuja tradução é de Pedro Ipiranga Júnior. Tomemos como exemplo o parágrafo inicial de cada recensão:

Recensão G:

1. Esopo, que é de grande serventia em todos os aspectos da vida, o autor de fábulas, por uma circunstância do destino foi escravo e por nascimento, frígio - de Amorios, na Frígia. Repugnante ao olhar, ele era asqueroso: pançudo, cabeçudo, de nariz achatado, corcunda, negro, baixote, de braços curtos, manco, estrábico, beiçudo - uma aberração manifesta. E além disso tudo, tinha uma deficiência ainda pior que a deformidade, a mudez, pois era tanto banguela quanto incapaz de articular sons.

Recensão W:

1. Esopo, o compositor de fábulas, que se revelou de máxima utilidade por todo o seu gênero de vida, foi escravo, por questão de fortuna, e frígio, por sua origem, da cidade de Amório na Frígia. Era de aspecto medonho: testudo, entroncado no pescoço, de nariz acachapado, preto e beiçudo, pançudo e de bracinhos cotós, vesgo, corcunda - um erro do dia! Além disso, tinha a fala travada, emitia um som de voz rouco, todo desmazelado e terrível em trapaça. 
Esse início das duas recensões já revela o tipo de antiherói que a figura de Esopo representa, estando presente um tipo de crítica social a partir do seu estatuto de escravo. Toda essa sobrecarga no aspecto externo, cuja extrema feiúra é enfatizada quer pelo narrador, quer pela reação dos outros à primeira vez que vêem Esopo, vai ser contrastada ao longo da obra com a sabedoria de caráter pragmático que ele exibe nas mais variadas circunstâncias e que é exemplificada, em momentos-chave pela enunciação de fábulas. A construção do personagem também aponta para uma contraposição entre uma sabedoria popular, por ele representada, e uma cultura letrada e aristocrática, representada pelo personagem do filósofo Xanto, o patrão de Esopo na segunda parte da obra. Xanto, a princípio, um estoico, não deixa de exemplificar a figura do filósofo presunçoso e, em certa medida, charlatão que era escarnecida por Luciano de Samósata em vários de seus textos, como em $O$ fim de Peregrino, Leilão de Vidas, Hermótimo etc. Embora agraciado pelas Musas e por Ísis, na recensão G, e pela Tykhe, na recensão W, de forma semelhante, ele entra em conflito com a figura de Apolo, por ser o deus da bela forma e da alta cultura, segundo Jouanno. ${ }^{1}$

A pretensa figura histórica de Esopo é reportada por fontes antigas, a exemplo de Heródoto e Evagon de Samos, como tendo vivido na primeira metade do século VI a.C. ${ }^{2}$ Pelo testemunho de Heródoto teria sido companheiro de servidão da cortesã Rodópis, escravo de um mestre de Samos e teria perecido nas mãos dos habitantes de Delfos. Outros autores antigos, mormente Aristóteles, Heráclides de Lembos, o comediógrafo do século V a.C. Platão e sobretudo Aristófanes, fornecem outras informaçôes e completam o enquadramento biográfico de Esopo até essa época. Tais apontamentos biográficos levaram alguns autores, como Momigliano e Rosa Gianattasio Andria a conjecturarem sobre a possibilidade da existência de um bios de Esopo já no século $\mathrm{V}$ a.C. ${ }^{3}$

Segundo Andria, nas recensões que nos chegaram, seria possível discernir uma matriz narrativa antiga que remontaria a esse pretenso bios mais arcaico. ${ }^{4}$ Por seu turno, segundo Adrados, o núcleo básico da obra seria propriamente helenístico, por questôes de estilo e do modo de composição
1. Cf. JOUANNO, 2006, p. 34-41.

2. Cf. HERÓdoto, História, e, 134-135; FgrHist 535, F4.

3. ANDRIA, 1995, p. 23-56; cf. MOMIGLIANO, 1991.

4. Cf. também NAGY, Gregory. The Best of the Achaeans. Baltimore: The Johns Hpkins Univesity Press, 1979 
5. Cf. PERRY, 1952; PAPATHOMOPOULOS,

1999, p. 24-33; JOUANNO, 2006, p. $14-16$.

6. Cf. GALLO, 2007, p. 47-51. das fábulas que aí aparecem, tendo sido acrescentados detalhes ou episódios posteriormente na época imperial. Não obstante, em se tratando de gênero, a presença de fragmentos e de dados esparsos sobre Esopo em fontes mais antigas adquirem apenas um caráter conjectural, não sendo possível comprovar sua existência. $\mathrm{Na}$ opinião de boa parte dos especialistas, a data provável de composição seria um período que abarca o final do século I d.C. até meados do século II d.C., data essa em que se constitui e se consolida o chamado romance ideal grego, os romances de autoria de Luciano, Das Narrativas Verdadeiras e O Asno, assim como a Vida Herodoteana de Homero, que partilha de alguns traços em comum com a Vida de Esopo.

Há três recensões importantes da obra: a recensão $G$, Grottaferrata, a recensão W, Westermaniana (que possui duas redações ligeiramente diferentes: a redação MORNLo e a redação BPThSA) e a recensão Accursiana, esta redigida por Bonus Accursius em Milão em 1479-1480 e provavelmente obra de Máximo Planudes, no século XIII. Segundo Papathomopoulos, as recensōes G e W do RE adviriam de um arquétipo comum do século I d.C. Para Perry, apenas a recensão $G$ procederia do século I d.C., enquanto a $\mathrm{W}$ seria tardia, do século $\mathrm{V}$ d.C. Na perspectiva de Corinne Jouanno, nem a recensão $G$, muito menos a $W$ seriam representantes da forma original da Vida de Esopo, em vista do cotejo com fragmentos da obra conservados sobre papiros. O mais antigo desses papiros, P. Berol. Inv. 11628 , pressuporia uma data por volta do final do século I e início do século II, enquanto o arquétipo das duas recensões apareceria no século II ou III d.C. Isso aproxima o RE, pelo tratamento do tema e pela construção das figuras do narrador e do protagonista, das obras de escritores do século II d.C., mormente Plutarco, Luciano e Apuleio, assim como coincidiria com, como já havia sido dito, os primeiros exemplares dos romances antigos e com o movimento da Segunda Sofística. ${ }^{5}$

A VE, assim como o Romance de Alexandre, na acepção de Gallo, ${ }^{6}$ em vez de se constituírem como autênticas recensōes, teriam sofrido um processo de reescrita e revisōes constantes ao longo dos séculos, em vista da maior liberdade dos copistas em fazerem intervenções, alteraçōes 
e mesmo longos acréscimos aos textos. Em vez de uma estética popular, na linha de argumentação de Hansen, talvez se possa falar de uma espécie de poética compilatória romanesco-biográfica num duplo registro. Por um lado, no composicional, em que o pretenso autor ou autores (na maioria das vezes anônimos) estruturaria sua narrativa compilando obras mais antigas, como faz, por exemplo, Diógenes Laércio e o autor da VE; ${ }^{7}$ por outro lado, no sentido das várias reescritas do texto, em que alteraçōes, por vezes, significativas, impõem à narrativa uma dinâmica de absorção recorrente de segmentos textuais e diegéticos heteróclitos.

A despeito dessa poética compilatória e de uma estrutura compósita, verifica-se na VE, por exemplo, uma certa unidade literária, cujos diversos paralelismos ao longo da narrativa fazem pensar numa elaboração consciente da totalidade da obra. Papathomopoulos, a partir dessa ótica, divide a obra em três seções consoante os três lugares de atividade de Esopo: a primeira seção (capítulos 1-100) incluiria duas partes: $\alpha$ ) as aventuras de Esopo enquanto escravo do primeiro senhor, aquisicão da voz e sua exposição à venda; $\beta$ ) sua venda, sua estadia junto a Xanto, sua liberacão, seu papel político mediador entre os sâmios e Creso, a construção de uma estátua em sua honra. A segunda seção (capítulos 101-123) abarcaria as peripécias de Esopo junto ao rei da Babilônia Licurgo e ao faraó do Egito, Nectanebo, seção esta que constitui uma adaptação e reescrita da famosa narrativa oriental relativa a Ahicar. $\mathrm{Na}$ terceira seção (capítulos 124-142) é narrada a viagem de Esopo à Grécia e suas peripécias que terminam com sua morte ocasionada pelos habitantes de Delfos. ${ }^{8}$

A favor dessa unidade diegético-estrutural da obra, Niklas Holzberg apresenta duas colocaçôes fundamentais: 1) no que diz respeito à relação do autor anônimo com suas fontes, os escritor não reúne as diversas partes de maneira aleatória e arbitrária, mas mostra um plano narrativo coeso, com paralelismos e outros recursos estilísticos, reunindo de forma coerente ditos e feitos de Esopo a partir das narrativas legendárias de Hesíodo, dos sete sábios, de Sócrates, de Diógenes, além, é claro, da antiga tradição biográfica sobre Esopo; 2) no que diz respeito à relação da narrativa com os
7. Emprego a partir de então a sigla VE para Vida de Esopo e R. Alex. para Romance de Alexandre.

8. PAPATHOMOPULOS, 1999, p. 18-19. 
9. Cf. HOLZBERG, Niklas (ed.). Der ËsopRoman. Motivgeschichte und Erzählstruktur. Tübingen, 1992;cf. PAPATHOMOPOULOS, 1999, p. 20-21; cf. JOUANNO, 2006, p.28.

10. O relato da Vida pode recuar, no entanto, até o século segundo de nossa era, como atestam os papiros mais antigos encontrados. Recentemente L. Kurke (2011) discute extensivamente a questão, passando em revista as hipóteses de que versões anteriores da Vida de Esopo tivessem circulado desde o século VI a.C., remontando, talvez, a um estágio oral de composição e transmissão e refletindo uma origem popular. Além da G, as outras recensões são a Westermanniana (W) e a Planudea (Pl.), datadas de XI e XIII d.C. respectivamente. discursos esópicos aí inseridos, monólogos, diálogos e fábulas, sua inserção é funcional e não artificial, prestando certa justificação em cada momento do contexto biográfico. Seriam, segundo ele, três os tipos do discurso esópico: tipo A, admoestação ou advertência direta; tipo B, resolução de um problema (missão complicada, pergunta, enigma); tipo C, fábula narrada por Esopo em uma situação difícil. Esses três discursos se distribuiriam de forma simétrica ao longo das unidades da obra, unidades que Holzberg divide em cinco: 1) na história inicial (capítulos 1-19), em que Esopo está mudo, tais discursos não se encontrariam; 2) parte de Esopo junto a Xanto (capítulos 20-91), onde aparecem os discursos tipo A e B; 3) na parte em que Esopo ajuda os sâmios (capítulos 92-100), presença do tipo C (com resultado positivo); 4) na parte em que Esopo auxilia o rei da Babilônia Licurgo (capítulos 101-103), novamente os tipos A e B aparecem; 5) na parte final, nas desventuras de Esopo junto aos délfios, aparece de modo simétrico o tipo C, com resultado negativo. ${ }^{9}$ Por conseguinte, uma análise mais acurada do texto contradiz sua inorganicidade e relativiza seu caráter meramente compilatório.

Das três versões conhecidas da Vida de Esopo, o mais antigo manuscrito, datando de $\mathrm{X}$ d.C. ${ }^{10}$ diz respeito, como visto, à recensão $G$, assim denominada por ter pertencido originalmente ao acervo da Abadia de Santa Maria de Grottaferrata (Itália). Transmitida através de um códice único, sua existência permaneceu ignorada até aproximadamente um século atrás quando foi descoberta em uma biblioteca de Nova Iorque (EUA), a Pierpont Morgan Library, e editada por Ben Perry em sua Aesopica (1952). Nos anos noventa, foi republicada nas edições de Manolos Papathomopoulos (Ioannina: 1990) e Franco Ferrari (Milano: 1997), essa última adotada para a tradução desta recensão.

Embora as três versões ( $\mathrm{G}, \mathrm{W}$ e $\mathrm{Pl}$ ) coincidam em grande parte quando aos episódios que compõem a vida de Esopo, a recensão $\mathrm{G}$ é mais longa que as demais e confere à linguagem um tratamento peculiar. Sem aparentar ter sofrido com censuras ou expurgos significativos, embora o manuscrito traga algumas lacunas dignas de nota (cf. início de 2), ora apresenta linguagem elevada, como por exemplo nos capítulos em que se narra o encontro de Esopo com a 
sacerdotisa de Ísis e a epifania da deusa (5-7), ora descamba no seu contrário, abusando de detalhes escatológicos ou obscenos, como por exemplo a o episódio do vômito dos figos (3). Por seu turno, na recensão W, embora os sacerdotes sejam da religião isíaca, não aparecem Ísis e as Musas, mas a Tykhe, a figura da Fortuna personificada.

A maior parte de editores e tradutores costumam traduzir a recensão $G$, considerada a mais antiga, suplementando suas lacunas com passagens da recensão W. Em vista de oferecermos uma visão mais clara das duas recensões, optamos por fazer traduçōes separadas de cada uma, porém, em função do escopo desse dossiê, restringimos nossa tradução à primeira parte da primeira seção da obra. A posteriori, cada um dos autores publicará, separadamente, a tradução completa de cada uma das duas recensões.

\section{Recensão G: ${ }^{11}$}

O livro de Xanto, o filósofo, e de Esopo, seu escravo (ou Sobre a vida de Esopo)

1. Esopo, que é de grande serventia em todos os aspectos da vida, o autor de fábulas, por uma circunstância do destino foi escravo e por nascimento, frígio - de Amorios, na Frígia. Repugnante ao olhar, ele era asqueroso: pançudo, cabeçudo, de nariz achatado, corcunda, negro, baixote, de braços curtos, manco, estrábico, beiçudo - uma aberração manifesta. ${ }^{12}$ E além disso tudo, tinha uma deficiência ainda pior que a deformidade, a mudez, pois era tanto banguela quanto incapaz de articular sons.

2. Seu senhor, julgando-o absolutamente detestável e incapaz para o trabalho na cidade, enviou-o ao campo. [... $]^{13}$ Um seu colega de servidão [Hermas], vendo o companheiro [Agátopo] sofrer, disse-lhe: "Meu irmão de servidão, sei o que está pensando, que quer devorar os figos." "Sim, por Zeus! Como você sabe?" "Pelo jeito do olhar conheço o que vai pela alma", disse. "Dê então um conselho de como os comeremos, nós dois". E ele: [... $]^{14}$ "Não é um bom conselho, pois quando o senhor procurar os figos e não pudermos dá-los, o que será?" E ele respondeu: "Diga que
11. Tradução de Adriane da Silva Duarte. De um total de 142 "capítulos", traduzem-se aqui os primeiros 19, que narram as desventuras de Esopo no cativeiro na Frígia, a graça concedida a ele por Ísis, sua aquisição pelo mercador de escravos que o conduzirá a Samos, cenário de parte significativa de sua história.

12. Adoto aqui a correção de Perry: троonuâivov para a crux interpretatio пробнптаิіоs.

13. Texto mutilado. Do cotejo com a recensão $\mathrm{W}$ depreende-se que o senhor de Esopo, em visita ao campo, é presenteado com os primeiros figos da colheita e os confia a seu escravo Agátopo. Este trama com um colega para comê-los e colocar a culpa em Esopo.

14. Lacuna no texto. Supressão do conselho? 
15. Note-se que o episódio segue o modelo da fábula e se encerra pela moral (epimítio). $\mathrm{Na}$ recensão W, ela vem versificada: ö $\sigma \mathrm{TIS} k \alpha \theta^{\prime}$

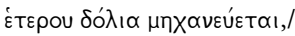
aútòs $k \alpha \theta^{\prime}$ aútoû toûto

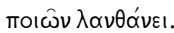

Esopo encontrou a despensa aberta providencialmente, pulou para dentro e devorou os figos. Como Esopo não pode falar, será surrado e você terá satisfeito seu desejo". Dito isso, sentaram-se ao redor dos figos e os devoraram, dizendo: "Dane-se Esopo! Ele é mesmo asqueroso e não presta para mais nada a não ser apanhar. Vamos combinar entre nós de uma vez por todas, sempre que alguma coisa quebrar, estragar ou derramar, dizemos que foi Esopo que fez e ficamos livres de qualquer ataque". E eles devoraram os figos.

3. Na hora acordada, após ter se banhado e almoçado, e com apetite para os figos, o senhor mandou buscar o produto da colheita e disse: "Agátopo, entrega-me os figos!" E ele: "Hermas, traga os figos!" O senhor, ao perceber que eles zombavam, ficou transtornado e, sendo informado que Esopo comera os figos, disse: "Que chamem Esopo!" E ele, ao ser chamado, apresentou-se. E o senhor lhe disse: "Diga, desgraçado, você me despreza tanto, para entrar na despensa e devorar os figos separados para mim?” Ele ouviu, mas sem poder falar devido sua língua travada e encarando diretamente seus acusadores manifestos, como estava prestes a apanhar, caiu aos joelhos de seu senhor e suplicou que esperasse um pouco. Ele acedeu e Esopo, vendo um jarro ao seu lado, pegou-o e com um sinal de cabeça pediu água morna. Após dispor uma bacia no centro do aposento e beber a água, colocou os dedos dentro da boca e, e forçandoa, devolveu a água morna que bebera. Nada de outro havia provado. Graças ao seu expediente, deu prova de inocência e exigiu que seus colegas de servidão fizessem o mesmo, para que fosse conhecida a identidade do devorador de figos. Admirado com o raciocínio dele, o senhor ordenou que também os outros bebessem e vomitassem. Os escravos disseram entre si: "O que faremos, Hermas?" "Vamos beber, mas não vamos colocar os dedos lá no fundo, e, sim, para os lados”. Assim que eles beberam a água morna, os figos produziram bile e refluíram. E assim que tiraram os dedos, os figos saíram de um jato. E o senhor disse: "Ora vejam, como caluniaram o que não pode falar? Dispam-nos!” Ao serem surrados, eles descobriram que aquele que planeja o mal contra um outro, contra si próprio o faz sem perceber. ${ }^{15}$ 
4. E eles então foram punidos em vista dos erros cometidos contra o que não podia falar. [...a cidade.] ${ }^{16}$ Quando Esopo estava a lavrar no campo, uma sacerdotisa de Ísis, por acaso, afastou-se do caminho público e ingressou no campo, onde Esopo estava a lavrar. Ao ver que ele executava seu trabalho penosamente, e ignorando sua condição, ${ }^{17}$ disse: "Moço, se tem piedade de almas mortais, mostre-me, que estou perdida, o caminho que conduz até a cidade". Quando Esopo se voltou e contemplou um ser humano portando o emblema da deusa, porque era piedoso, prosternou-se e começou a sinalizar com a cabeça como que e a indicar: "Por que você abandonou o caminho público e ingressou nessa propriedade?" Percebendo que ele ouvia, mas não podia falar, ela começou a fazer sinais ${ }^{18}$ para ele enquanto falava: "Sou uma estrangeira nesse lugar. Como você vê, sou sacerdotisa. Em vista da minha ignorância, peçolhe, mostre-me o caminho, que estou perdida". Pegando novamente a foice com a qual lavrava, Esopo tomou-a pela mão e conduziu-a até o arvoredo. Ali, de seu alforje, serviu pão e azeitonas, colheu e trouxe alface selvagem, e insistiu que ela compartilhasse o alimento. E ela compartilhou. Depois, conduziu-a até uma fonte de água e mostrou-a, caso também quisesse compartilhar dela. Tendo compartilhado o alimento e a bebida, dirigiu as preces mais belas em intenção de Esopo. E, por sinais, pediu-lhe novamente que pusesse fim aos favores e lhe mostrasse o caminho. E ele a conduziu até a estrada principal, por onde passavam carros, e, mostrando-a, afastou-se e concentrou-se no trabalho.

5. A sacerdotisa de Ísis, pegando novamente a estrada e lembrando-se da gentileza de Esopo, ergueu as mãos para o céu e disse: "Diadema do mundo habitado, Ísis dos mil nomes, tem pena deste trabalhador, que é sofredor, que é piedoso, em vista da piedade demonstrada, não para comigo, senhora, mas para com os teus emblemas. E se não queres tornar a sua vida digna de riquezas, do que outros deuses privaram-no, ao menos agracia-lhe com o dom da fala. Tu és poderosa para trazer o que jaz nas trevas de novo para a luz". Após a sacerdotisa ter feito tal prece, Ísis, a soberana, ouviu. Rapidamente a palavra sobre a piedade alcança o ouvido dos deuses.
16. Lacuna no texto o manuscrito. O cotejo com a recensão $\mathrm{W}$ permite suplementar assim a frase: "No dia seguinte, o senhor sentou-se em seu carro e voltou para a cidade".

17. Mais provável que a condição (Túxฤv) aqui referida seja a mudez e não à escravidão, embora em 1. leia-se: $T \dot{\nu} \nu \mu \dot{\varepsilon} v$

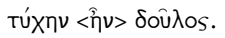

18. É de se estranhar que ela, tendo constatado que Esopo ouvia bem, usasse sinais ao falar com ele. 
19. Texto corrompido de difícil leitura.
6. Como o calor estava forte, Esopo disse para si mesmo: "Tenho duas horas longe do capataz para um descanso. Vou dormir durante essas horas de calor ardente". Escolheu na propriedade um lugar florido e tranquilo, arborizado e sombreado, no qual flores multicores cresciam da relva verdejante, envolvendo o lugar através da mata vizinha e do prado. Esopo, reclinando-se na relva e jogando por terra o forcado, o alforje e, sob a cabeça, colocando o gibão, descansou ali onde o rio murmurava rodeado pelas árvores. Zéfiro trazia um doce sopro e, sacudida, a verde folhagem bafejava uma brisa, doce e agradável, e muita cigarra sobre os ramos cantarolava e aves multicores, ruidosas, faziam eco à parolagem. Ali, onde estava o rouxinol de triste canto, os ramos de oliveira se condoíam, e sobre o pinheiro delgado o ímpeto aéreo devolvia a imitação de um melro. ${ }^{19} \mathrm{E}$ o eco, que imita sons, mesclando-se a tudo em uníssono, plangia. Essa mescla de todos os sons resultava num murmúrio harmonioso. Sob seu efeito, seduzido, Esopo mergulhava em doce sono.

7. Ali a deusa, Ísis soberana, apresentou-se na companhia das nove Musas e então disse: "Olhem, filhas, a morada da piedade, este homem, que, apesar de deformado, derrota toda censura. Ele, um dia, quando estava perdida a minha serva, conduziu-a de volta a estrada. E estou aqui, com vocês, para recompensá-lo. Eu the devolvo a voz e, vocês, concedam a esta voz a graça da palavra excelente". Após dizer isso, cortou o nódulo da língua, empecilho à fala, e Ísis pessoalmente agraciou-lhe com a voz. Em seguida, persuadiu cada Musa a conceder-lhe um dom específico e elas o agraciaram com a inventividade da palavra justa, com a intriga de fábulas gregas e sua composição. Depois de fazer votos para que ele se tornasse célebre, a deusa partiu para sua morada. E as Musas, após terem-no agraciado cada uma em particular, retornaram para o monte Hélicon.

8. E depois de dormir segundo o comando da natureza, Esopo despertou e disse: "Puxa, como dormi bem! Estou falando sem impedimento e dando nome ao que vejo: forcado, bolsa, gibão, alforje, boi, asno, ovelha. Estou falando, pelas Musas! De onde recebi o dom da fala? De onde? Já sei! Com certeza foi em troca de minha piedade 
para com a sacerdotisa de Ísis, de modo que vale a pena ser piedoso! Espero agora que, da parte dos deuses, venham a se cumprir nobres esperanças".

9. Muito contente com o acontecido, ele retomou o forcado e se pôs a lavrar. O capataz da propriedade, investindo contra os trabalhadores, açoitou um dos colegas de Esopo com uma vara. E Esopo, sem mais poder controlarse, disse: "Homem, por que você maltrata assim cruelmente aquele que não cometeu erro algum e bate sem dó, logo você que a todo o momento comete erros mais numerosos sem ser castigado por ninguém?" E Zenas disse para si mesmo: "O que é isso? Esopo agora fala? Pelos deuses, mal começou a falar e já se bate comigo, que falo com ele e lhe dou ordens, e com nenhum outro. Se não o denuncio valendo-me de um pretexto, ele pode me destituir da administração da propriedade. Com efeito, quando ainda era banguela, deu a entender através de sinais que: 'quando o senhor vier, vou tirar você da administração da propriedade, pois vou denunciá-lo através de sinais'. Se prometia fazê-lo com sinais, persuadirá muito mais falando. É melhor, portanto, tomar a dianteira".

10. Montou sobre o cavalo e num ímpeto foi até a cidade. Chegando à casa do senhor, saltou do cavalo. Após prender a rédea na argola do portão, entrar na casa e encontrar o amo, disse: "Senhor!" E ele disse: "Zenas, por que você está tão perturbado?" E Zenas respondeu: "Uma coisa prodigiosa aconteceu em sua propriedade". E ele disse: "Que alguma árvore não tenha dado fruto fora da estação!" E ele disse: "Não, meu senhor". "Será, então, que um quadrúpede deu à luz um humanoide", disse o senhor, "ou algo assim?" E Zenas responde: "Não, meu senhor". E ele: "Então, o que você chama prodigioso? Conte logo a verdade." E Zenas disse: "Esopo, o asqueroso, que você despachou para o campo, para lavrá-lo, o pançudo...” E o amo: "O quê? Pariu?!” E ele: "Não! Mas ele, que era banguela, falou". E o senhor: "Tomara que nada de bom te aconteça! Você chama isso prodigioso?" Zenas: "Claro, e muito". E o senhor: "Por quê? Se acaso os deuses, irritados com um homem, durante um breve tempo privaram-no da voz e agora, reconciliados, agraciaram-no novamente, o que parece 
20. Adoto aqui a solução de Perry: $\alpha$ $\pi \hat{\alpha} \rho \alpha ı$ por

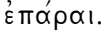

21. O nome do mercador é Ofelião $\left(\Omega \phi \varepsilon \lambda i \omega^{\prime} \omega \nu\right)$, do verbo grego $\omega \dot{\phi} \varepsilon \lambda^{\prime} \dot{\omega} \omega$, ser util. Traduzo por crer significativo que Esopo use como argumento para persuadi-lo a comprá-lo sua "utilidade", garantida por um juramento a Ísis, sua protetora. Ao fim, Utílio será útil a Esopo por livrá-lo da fazenda e levá-lo para Samos, onde será vendido a Xanto. Cf. parágrafo 15: $\omega \dot{\phi} \varepsilon \lambda \eta \dot{\sigma} \sigma \omega$ (serei util), $\omega \phi \varepsilon \lambda \hat{\eta} \sigma \alpha$ । (ser util). ter acontecido, você acha mesmo que é prodigioso?” Zenas: "Acho, senhor, porque mal começou a falar e se pronuncia sobre tudo de modo impróprio a sua condição. Contra mim e contra você blasfema enormemente, coisas que nem as minhas orelhas aguentam ouvir. Não quero repetir o que ele disse contra você, quando observei que o meu senhor o tem por imprestável, porque não prestava para o trabalho na cidade, e enviou-o para o campo".

11. E ele, incomodado, disse a Zenas: "Vá e venda-o!" E Zenas: "É brincadeira, senhor? Não conhece a deformidade dele? Quem vai querer comprá-lo e ficar com um babuíno em lugar de um homem?" E o senhor: "Então vá e doe a alguém. Caso ninguém queira ficar com ele, esfole e mate-o". Zenas, tendo recebido carta branca para agir, novamente saltou para o cavalo e retornou à propriedade. E Zenas ia dizendo consigo mesmo: "O senhor me deu carta branca no que respeita Esopo: vender, doar, assassinar. Que mal ele me fez para que o mate? Vou vendê-lo". Eis como tudo que foi acordado a Esopo pelos deuses pôs-se a seu favor.

12. Aconteceu que um mercador de escravos, montado em um cavalo, vinha do campo para a cidade. Querendo aliviar ${ }^{20}$ suas peças, buscava alugar animais de carga do campo, mas como não achou nada, voltava para a cidade. Ao encontrá-lo, Zenas saudou-o, já que eram conhecidos, dizendo: "Salve, Utílio, ${ }^{21}$ mercador-mor!" E ele: "Salve, Zenas, camponês-mor!" E Utílio perguntou: "Zenas, você não teria por acaso animais de carga para alugar ou vender?" E Zenas: "Não, por Zeus, mas tenho um escravo para vender, um macho de bom preço, se você quiser". E o mercador, acostumado a viver disso: "Você pergunta a mim, que sou mercador de escravos, se quero comprar uma peça de bom preço?" E ele: "Venha então até a propriedade vizinha".

13. Zenas levou-o até o campo e disse: "Mandem um dos colegas de servidão até a plantação para chamar Esopo". E um dos colegas foi e, ao avistar Esopo, que lavrava, disse a ele: "Largue o forcado e siga-me, o senhor está chamando". E ele disse: "Qual senhor? O de direito ou o capataz? Faça a distinção com clareza e diga 'o capataz', e, não, 'o senhor', já que aquele também está sob o jugo da servidão como 
qualquer escravo". E o outro: "Olha só que reviravolta! A troco do quê? Mal começou a falar e já está todo metido!” Esopo largou o forcado e disse: "Como a escravidão é uma herança maldita e, mais que isso, detestada pelos deuses! Esopo, ponha a mesa! Esopo, aqueça a água do banho! Esopo, vá buscar água! Esopo, dê comida aos animais! Tudo quanto é penoso, cansativo, cheio de sofrimento ou servil a Esopo ordena-se que faça. Cuidam que não possuo o dom da palavra, atribuído a mim pelos deuses? O senhor virá e, no momento oportuno, eu acusarei e destituirei o capataz. Por ora devo me submeter. Conduza-me, então, meu irmão de servidão". Apresentaram-se e ele disse: "Senhor, eis aqui Esopo". Zenas disse: "Mercador-mor, passe-o em revista!"

14. Quando o mercador de escravos se virou e viu Esopo, desconjuntado e esfarrapado, disse: "Só pode ser o corneteiro da batalha dos grous! ${ }^{22}$ É o bulbo de um junco ou um homem? Se ele não pudesse falar, eu acharia que é um caldeirão com pés, uma marmita ou um ovo de gansa! Devo zangar-me com você, Zenas. Por que me tirou do caminho, quando já poderia ter completado minha viagem, como se tivesse algo de bom para vender e não esse bode expiatório?" Disse isso e se pôs a caminho.

15. Quando estava saindo, Esopo puxou-o pela ponta do manto e disse: "Ouça!" E o mercador disse: "Solte! Tomara que nada de bom te aconteça! Por que me chama de volta?" E Esopo disse: "Por quem você veio aqui?" E ele: "Por sua causa, para comprá-lo". "E então", perguntou Esopo, "por que não me compra?" O mercador: "Não fique me rodeando, por favor, porque não quero mesmo comprar". Esopo: "Compre-me, homem! Juro por Ísis que serei muito útil a você". Mercador de escravos: "No que você pode me ser útil, para que eu o compre iludido pela esperança?” Esopo: "Você não tem em seu mercado uns meninos mal-educados que pedem comida a toda hora?" Mercador de escravos: "Tenho". Esopo: "Compre-me e faça de mim seu instrutor. Com medo de minha cara feia, eles vão deixar de cantar vitória". Mercador de escravos: "A ideia vem em boa hora. Sim, pela malícia que há em sua cor!23" O mercador de escravos deu meia volta e disse a Zenas: "Por quanto você vende esse desgraçado?" Zenas respondeu: "Por três óbolos".
22. Referência a batalha dos grous contra os pigmeus (Ilíada, III, 37). Esopo é comparado a um pigmeu.

23. Em grego, lê-se: $\mu \alpha \grave{~ т ท ่ v ~ \sigma к o ́ t ı \alpha ~ \sigma o u, ~ p e l a ~}$ sua escuridao/negritude! Há uma alusão clara à pele escura de Esopo, referida no parágrafo 1 ( $\left.\mu \varepsilon^{\prime} \alpha_{\varsigma}\right)$, mas tambem a engano e trapaca, como atesta a acepção 8 do verbete бкótos, escuro, do LiddelerScott. 
24. O texto traz Ásia, mas, pressupondo que o trajeto começa em Amorios, interior da Turquia atual, e finda em Éfeso e Samos, cidade e ilha na costa deste mesmo país, entende-se que a referência é ao litoral da Ásia Menor.
Mercador de escravos: "Por quanto mesmo?" Zenas: "Pague o que quiser". E o mercador de escravos, pagando uma ninharia, comprou-o.

16. Quando chegou à cidade, ele o conduziu ao seu mercado. Dois meninos, que mamavam em sua mãe, ao avistar Esopo, gritaram e se esconderam. E Esopo disse para o mercador de escravos: "Eis a prova do que anunciei, que você comprou uma aberração na medida para meninos maleducados". O mercador de escravos riu e disse a ele: "Ali no refeitório estão reunidos os seus colegas. Entre e vá cumprimentá-los". Esopo foi adiante e encontrou escravos belíssimos, impecáveis mesmo, uns Dionisos e Apolos. Cumprimentou-os, dizendo: "Olá, irmãos de servidão!" Houve um murmúrio geral. Esopo: "Amigos, irmão de servidão sou de vocês, embora asqueroso". E os escravos disseram uns para os outros: "Sim, por Nêmesis, o que aconteceu para que o patrão comprasse uma peça assim tão feia?" E outro: "Você sabe por que ele o comprou?" E outro ainda: "Por quê?" "Para torná-lo amuleto do mercado de escravos ora".

17. O mercador entrou e disse para seus escravos: "Rapazes, conformem-se com sua sorte. Em que pese a integridade física, não achei animais de carga nem para alugar nem para comprar. Por esta razão dividam entre si a bagagem, já que amanhã seguiremos para o litoral". ${ }^{24} \mathrm{E}$ eles, formando pares, dividiram a bagagem entre si. Esopo prosternou-se diante de todos e disse: "Meus colegas, peçolhes, já que sou novato e fisicamente mais fraco, concedamme carregar uma carga leve". Eles responderam: "Não precisa carregar nada". E Esopo disse: "É uma vergonha que, com todos os colegas dando duro, eu me mostre imprestável ao patrão". Seus colegas de servidão disseram para si mesmos: "O quê? Ele está dando uma de fanfarrão? Carregue o que quer então".

18. Olhando a sua volta, Esopo avistou a bagagem do mercador de escravos para a viagem: uma cesta, esteiras, sacos cheios de todo tipo de utensílio, cobertas, vasilhas, cestos de mantimentos. Ao ver no chão um cesto cheio de pães que quatro queriam transportar, Esopo disse: "Amigos, deixem esse cesto só para mim". Os escravos disseram para 
si mesmos: "Nunca vimos ninguém mais tolo que esse nanico! Pediu para levar o mais leve e escolheu o mais pesado de tudo". E um outro: "Não é tolo, mas esfomeado. Quer ter os pães à mão e mastigar mais que todos. Deixemos para ele o cesto." E todos, ao seu redor, colocaram sobre ele o cesto de pães. E ele partiu, carregando o cesto como Atlas, sacudindo-se todo. Ao vê-lo, o mercador de escravos disse admirado: "Olhe só como Esopo é o mais animado para o trabalho! Ele incita os demais a suportar de boa vontade a fadiga. Já recuperei o preço pago por ele, já que esse carregamento é digno de um animal de carga”.

19. Os demais colegas carregavam a bagagem e riam dele, pois, ao pegar a estrada, ele ensinava o cesto a andar. $\mathrm{Na}$ subida, deitava o cesto e com os dentes puxava até que subisse; na descida, descia com facilidade, rolava o cesto para baixo e ele próprio, em cima dele, rolava também. E aos trancos e barrancos chegaram à hospedaria. $\mathrm{O}$ mercador de escravos disse: "Hospedeiro, dê um asse de comida a cada um, já temos os pães. Esopo, dê a cada um par de pães”. E com tantos escravos para receber o pão, o cesto esvaziou-se pela metade. Refeitos, seguiram novamente viagem. Esopo ia leve. ${ }^{25}$ Novamente chegaram a uma hospedaria, novamente ele distribuiu o pão para eles, e o cesto ficou vazio. E lançando o cesto sobre o ombro, corria na frente de todos. Os escravos disseram para si mesmos: "O que corre na frente de todos, quem é? Um de nós ou um forasteiro?" E um outro: "Não sei. Parece que é o novato, o asqueroso, o que ergueu um cesto que um animal de carga não levava". E outro ainda: "Você ignora que o homenzinho é pleno de juízo". E aquele: "Esses nanicos, o que têm de feios, têm de sensatos. Pediu para carregar os pães que foram consumidos de mão em mão. Enquanto isso nós carregamos cestas, cobertas e utensílios de bronze que não podem ser consumidos". Outro ainda: "Puxa, o homenzinho vale um por um touro!"26

\section{Recensão W: ${ }^{27}$}

1. Esopo, o compositor de fábulas, que se revelou de máxima utilidade por todo o seu gênero de vida, foi escravo, por questão de fortuna, e frígio, por sua origem, da cidade
25. Mantive a leitura de Perry sobre a colocação

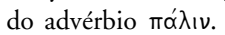

26. Sigo aqui a edição de Perry (e do códice).

27. Tradução de Pedro Ipiranga Júnior. Sigo o texto editado por Papathomopoulos em 1991; em alguns passos, adoto lições da edição de Karla. 
de Amório na Frígia. Era de aspecto medonho: testudo, entroncado no pescoço, de nariz acachapado, preto e beiçudo, pançudo e de bracinhos cotós, vesgo, corcunda um erro do dia! Além disso, tinha a fala travada, emitia um som de voz rouco, todo desmazelado e terrível em trapaça.

2. Sendo ele imprestável para o serviço na cidade, seu senhor o despachou a uma de suas propriedades para o trabalho de cultivo do solo. Um dia então em que apareceu no campo, um camponês, que havia colhido figos maravilhosos, trouxe ao senhor de Esopo e disse: "Fica, patrão, com tuas frutas da colheita inicial”. E o senhor, muito animado, disse: "Salvação minha, que belas frutas!" E disse ele ao criado: "Agátopo, fica com essa frutas e guarda para mim; depois que tomar banho e almoçar, me traga as frutas." Aconteceu que, nesse momento, Esopo voltou e entrou para buscar o pão do dia. Agátopo pegou os figos e, tomado de desejo, comeu um , dois e falou a um colega seu dos servos: "Queria me fartar dos figos, mas tenho medo." E o outro lhe disse: "Se eu puder também comer junto contigo, vou te dar uma ideia de como comer sem apanhar." E disse Agátopo: "Como?" E o outro: "Vamos comer os dois os figos e, quando o patrão mandar buscar, diga a ele que Esopo , achando oportunidade quando entrou, devorou os figos. E Esopo, por sua vez, de fala travada para fazer sua defesa, vai ser açoitado, enquanto nós vamos satisfazer nosso desejo." E eles, assentando-se junto com os figos, foram comendo um a um, e ainda diziam: "Coitado de ti, Esopo!" E, pondo-se de acordo entre si no sentido de que, qualquer coisa que se perdesse ou extraviasse, diriam que era obra de Esopo, devoraram assim os figos.

3. Depois de tomar banho e de almoçar, o senhor disse: "Agátopo, me arranje os figos." E o outro disse: "Patrão, Esopo, ao achar oportunidade encontrando o depósito aberto, entrou e devorou os figos." E o senhor, enraivecido, disse: "Alguém mande chamar Esopo até mim." E esse veio à sua presença. E disse o senhor: "Me diga, desgraçado, é tão grande o teu desprezo por mim a ponto de ter entrado no depósito e acabado com os figos, preparados para mim?" E aquele, sem poder falar travado na língua, percebendo que os seus acusadores eram os que estavam à sua vista $e$ 
que iria ser açoitado, caiu aos pés do senhor e suplicou para que ele esperasse um pouco. Pegou, então, um copo, colocou uma mistura de água morna, trouxe uma bacia, bebeu, distendeu os dedos boca adentro e, provocando a si mesmo, regurgitou apenas a água que tinha bebido, comprovando, pois, que não havia experimentado de nenhuma outra coisa. E também pedia para que seus acusadores fizessem da mesma forma e aí "saberá o senhor quem devorou os figos". Os servos então maquinaram enfiar os dedos pelas bochechas e não soltar garganta abaixo; no entanto, pela ação conjunta de beberem água morna e de se inclinarem, os figos, sendo produtores naturais de bílis, jorraram para fora e saíram de forma espontânea. Disse, então, o senhor: "Por que incriminaram falsamente alguém incapaz de falar?" $E$ ordenou que os dois, depois de despidos, fossem açoitados. E eles reconheceram de maneira clara que:

Quem contra outro trama ardis,

ele próprio desavisadamente age contra si mesmo!

4. No dia seguinte, o senhor, depois de se assentar num carro, partiu para a cidade. Esopo estava fazendo o trabalho de cultivo no campo, quando chegaram os sacerdotes de Ísis, os quais haviam se perdido da via principal. Eles rogavam a Esopo para que lhes mostrasse o caminho que conduzia a cidade. Esopo, dessa feita, depois de leválos até uma árvore cheia de sombra, ofereceu-lhes pão, azeitonas, figos secos e os forçou a comer; correndo, em seguida, até o poço, dali retirou água e trouxe para eles beberem. E, segurando em suas mãos, conduziu-os à ampla e costumeira via para seu caminho.

5. Eles alçaram as mãos ao céu e, depois que fizeram suas preces por ele em vista de sua boa ação, foram embora.

6. Esopo encaminhou-se de volta e, enlanguescido pelo calor, caiu no sono.

7. E a Tykhe, sobrevindo durante seu sono, agracioulhe com uma capacidade discursiva excelente, agilidade de fala e com uma inventividade virtuose em narrativas fabulosas variadas, pelo fato de ter ele agido amavelmente ante a divindade e ante aqueles que recebeu. 
8. Esopo, então, desperto do sono, disse: "Uai! Quão foi agradável ter dormido este sono! Tive também a visão de um belo sonho e ora vejam só; agora sem trava e sem dificuldade consigo falar e nomear aquilo que se apresenta à vista: enxadão, burro, boi, carro. Estou falando, pelos deuses! Por que será que recebi esta graça?" E disse: "Já sei! Foi por ter prestado ajuda aos estrangeiros e essa boa ação foi bem aceita pela divindade: ao que age bem estão reservadas boas expectativas!"

9. Radiante assim de alegria, Esopo pegou novamente o enxadão e começou a escavar o solo. $\mathrm{O}$ administrador da propriedade do campo, aparecendo no trabalho, começou a espancar um dos servos com um porrete. E Esopo, impressionado com a cena, disse: "Por que, homem de deus, tenta assim, a esmo e sem razão, acabar com alguém que não te prejudicou em nada? Mas eu vou declarar tudo isso ao senhor!" E Zenas (pois este era o nome do administrador), ao ouvir Esopo falando tais acusações, ficou cheio de pasmo e exclamou: "Esopo mal começou a falar e já me rebateu! Devo me antecipar a ele, pois, assim que o patrão vier e ele fizer as acusações, vai ele tomar meu lugar na administração da propriedade."

10. E, ditas tais palavras, subiu num burro e foi para a cidade. E, depois de se aproximar junto ao senhor, falou: "Olá!" E o outro disse: "Por que está assim tão perturbado?" E Zenas respondeu: "Patrão, uma coisa espaventosa aconteceu em tua propriedade do campo!" "O que?” Disse o outro. "Por acaso não foi uma árvore que produziu um fruto temporão fora da estação? Ou alguma besta de quatro patas gerou algo contra a natureza?" E o outro disse: "Não. Mas foi Esopo, aquele horroroso, que começou a falar desbragadamente!" E o senhor: "Nada de bom isso pode se afigurar para ti? Você acha isso um sinal assombroso? $\mathrm{Na}$ verdade, tem lá sua lógica: encolerizados com o homem, os deuses lhe tinham retirado a voz por algum tempo, mas agora, reconciliados, lhe agraciaram com ela novamente." Mas Zenas retrucou: "Patrão, mal começou a falar, seu modo de se expressar extrapola o de um homem normal, pois lança injúrias pesadas contra mim, contra ti e ainda grandes blasfêmias contra os deuses." 
11. E, cheio de ira, o senhor diz a Zenas: "Está bem! De agora em diante, ele te é dado como dádiva: venda, dê de graça, liberte, faça com ele o que quiser." Zenas, dessa feita, adquirindo autoridade sobre ele, foi até o campo e disse a Esopo: "Você foi dado a mim pelo senhor para fazer contigo o que me parecer melhor. Resolvi então te colocar à venda."

12. Aconteceu então de justamente aparecer pelo caminho um mercador de escravos; no momento que buscava bestas para alugar, ele encontrou Zenas, que já era seu conhecido, o cumprimentou e disse: "Você tem bestas para alugar ou vender?" E Zenas falou: "Não, mas tenho um escravo macho com um preço muito bom; se quiser, pode comprá-lo." E o mercador: "Me mostra esse então!"

13. E Zenas, depois de mandar trazê-lo, levou Esopo até ele e disse: "Aí está o servo; examina detidamente e faz a compra."

14. Ao virar-se e ver Esopo, soltou ele uma gargalhada e disse: "Como te apareceu esse panelão? É um homem ou uma espécie de cana ruidosa? É o tocador de trombeta de uma batalha de seres monstruosos!" ${ }^{28}$ Se não possuísse ele voz, eu diria que se tratava de um tumor provido de pele. Eh Zenas! Me fez desviar do meu caminho apenas por causa dessa porcaria, fazendo parecer que ia comprar algo que valesse a pena?" E depois de dizer essas palavras, se punha a ir embora.

15. Esopo, então, deu uma carreira até ele e disse: "Espera!" E o outro lhe disse: "Por que me aborda, seu lixo?" Esopo disse: "Por que veio até aqui?" O mercador: "Para comprar algo que achava que era de boa qualidade, mas você é um horror e eu não careço de algo assim tão ruim!" Fala Esopo, por sua vez: "Pode me comprar que eu vou ser de muita utilidade para você." E o outro lhe retrucou: "Em que você pode me servir?" E Esopo: "Você não tem no seu negócio de escravos uns garotos chorões ou desordeiros? Pode me comprar e me estabelecer como pedagogo; e eu me tornarei para eles um espantalho pavoroso fazendo as vezes de bicho-papão." Convencido pelo arrazoado, o mercador se voltou para Zenas e disse: "Por quanto você vende essa ruindade?" E Zenas disse: "Dois trióbolos." E o mercador,
28. Aqui aparece o termo teratomakhias. $\mathrm{Na}$ recensão $\mathrm{G}$, o termo usado é geranomakhias, como uma referência à batalha entre grous (géranos) e pigmeus. 
29. Como um óbolo era uma quantia insignificante para a compra de um escravo, um trióbolo seria, no caso, três vezes nada.

30. A lição adotada por Papathomopoulos é mórmeka, formiga, que no contexto não se adequa tão bem. Preferi a lição utilizada por Karla, mormolykion, uma espécie de espantalho. tendo rido, deu o trióbolo, considerando que tinha comprado nada mais que coisa alguma. ${ }^{29}$

16. Eles tomaram a estrada para a cidade e entraram no local de venda dos escravos. Duas crianças que estavam com a mãe, assim que viram Esopo, começaram a gritar e se esconderam. Disse Esopo ao mercador: "Tem aí já a prova do que te prometi; você comprou, de fato, um espantalho ${ }^{30}$ pronto para ser usado contra crianças sem vergonha." E o outro riu e falou: "Esopo, entra ao interior da sala e cumprimenta os servos teus colegas." Ao entrar, então, topa ele com jovens belíssimos e sem qualquer falha, e os cumprimenta dizendo: "Olá, colegas servos!" E eles disseram em uníssono: "Que horror, pelo deus Hélio! Que pode ter acontecido ao patrăo? Pois ele jamais comprou um escravo tão nojento! A não ser que tenha comprado o traste como amuleto e proteção do mercado de escravos contra mau olhado."

17. Entrando no recinto, o mercador disse aos servos: "Podem lamentar a sua sorte, pois não achei bestas de carga, nem para comprar nem para alugar. Dividam, portanto, bagagens e provisōes, pois amanhã vamos nos mandar para a Ásia." Os servos, então, aos pares iam dividindo as bagagens. E Esopo, caindo-lhes aos pés, falou: "Belos colegas de servidão, me concedam a carga mais leve, já que sou recém-comprado e fracote!" E disseram eles: "Se não puder, não carregue nada." Esopo falou: "Com todos se esfalfando, vai ser inaceitável que eu seja o único sem serventia para o patrão." Disseram, por sua vez: "Carrega o que quiser."

18. Ele, lançando um olhar ao redor, divisa aqui e ali objetos e vasos diversos para a jornada: sacos, colchōes e cestos. Ao reparar num cesto de pães que dois servos se dispunham a carregar, disse: "Coloquem essa carga sobre mim." Eles, então, diziam: "Quem seria mais imbecil do que este homem? Rogava para carregar a carga mais leve e escolhe de todas a mais pesada! Vamos satisfazer o desejo dele." Ao vê-lo, o mercador se admirou e disse: "Esopo é mesmo disposto para o trabalho duro, e ainda serve como incentivo aos outros para suportarem sua carga com firmeza de ânimo! Já recuperei o valor dado por ele, pois levantou uma carga própria de um animal." 
19. Os outros servos, em duplas, pegavam suas cargas e dele escarneciam. Ao pegar a estrada, ele ia aprendendo a caminhar manuseando o cesto. De fato, se ia numa subida, agarrava-se com unhas e dentes ao cesto e o rolava para cima; mas se ia numa descida, o rolava com bem mais rapidez. E assim se esforçava até que chegaram à estalagem. Desejando que os escravos recuperassem as forças, o mercador mandou que eles descansassem no chão. E disse a Esopo: "Distribua o pão." Entregue assim uma grande quantidade de pães, o cesto ficou esvaziado pela metade. Após terem os escravos restabelecido as forças, de novo se puseram em marcha e Esopo, com mais disposição, chegava até a hospedaria. Ao cair da noite, tendo distribuído o pão, seu cesto ficou vazio. No dia seguinte, com o cesto suspenso aos ombros, corria adiante de todos. E os outros servos diziam entre si: "Quem é esse que corre à frente? É algum estrangeiro desconhecido de nós?" Outro disse: "É aquele horroroso." E um outro dizia: "Vocês não reconhecem que este homenzinho, cheio de argúcia, agiu superando a todos nós? Pois nós nos acabamos de trabalhar carregando colchões e outras tralhas que não são consumíveis, enquanto aquele, trapaceiro, carregava pães que, de pronto, são consumidos.”

\section{EDIÇÕES E TRADUÇÕES}

Anônimo. Romanzo di Esopo. Introduzione e texto critico a cura de F. Ferrari. Milano: Rizzoli, 1997.

JOUANNO, Corinne. Vie d'Ésope, traduite et commentée par Corinne Jouanno, La Roue à Livres, Paris, 2006, 264 p.

KARLA, Grammatiki A. Vita Aesopi: Ueberlieferung, Sprach und Edition einer fruebbyzantinischen Fassung des Aesopromans. Serta Graeca: Beitraege zur Erforschung griechischer Texte, 13. Wiesbaden: Dr. Ludwig Reichert Verlag, 2001.

PAPATHOMOPOULOS, M. Ho bios tou Aisopou. He parallage $G$. Ioannina, 1990.

PAPATHOMOPOULOS, Manoles. O bios tou Aisopou : he parallage W. Editio princeps. Athens: Ekdoseis Papadema, 1999, 206 p. 
PERRY, B. E. (ed.) Vita Aesopi Vulgaris Qualis Exstat Unice In Codice G. In Aesopica. A series of texts relating to Aesop or ascribed to him. Urbana: University of Illinois Press, 2007 (1a ed. 1952).

PERRY, Edwin. Aesopica. A series of texts relating to Aesop or adscribed to him or closely connected with the literary tradition that bears his name. Urbana, Illinois: The University of Illinois Press, 1952.

\section{REFERÊNCIAS BIBLIOGRÁFICAS}

ADRADOS, Francisco Rodriguez. Historia de la fábula grecolatina. V. I. Introduction y de los origenes a la Edad Helenistica. Madrid: Editorial de la Universidad Complutense, 1979.

ANDRIA, Rosa Gianattasio. Il Bios di Esopo e I Primordi Della Biografia. In: Biografia e autobiografia degli antichi e dei moderni. A cura di Italo Gallo e Luciano Nicastri. Napoli: Edizione Scientifiche Italiane, 1995, p. 23-56.

BRANDÃO, Jacyntho Lins. A poética do hipocentauro: literatura, sociedade e discurso ficcional em Luciano de Samósata. 1. ed. Belo Horizonte: Editora UFMG, 2001. v. 1. 369 p.

BRANDÃO, Jacyntho Lins. A invenção do Romance. Brasília: Editora UNB, 2005.

BURRIDGE, Richard A. What are the Gospels? A Comparison with Graeco-Roman Biography. Michigan/ Cambridge: William B. Eerdmans Publishing Company, Gran Rapids, 2004.

GALLO, I. La biografia greca. Profilo storico e breve antologia di testi. Rubbettino: Soveria Mannelli, 2005.

GUIJARRO, Sergi Grau i. La imatge del filòsof i de l'activitat filosòfica a la Grècia antiga. Anàlisi dels tòpics biogràfics presents a les Vides i doctrines dels filòsofs més il.lustres de Diògenes Laerci. Tese de doutorado, Departament de Filologia Grega, Universitat de Barcelona, Barcelona, 2007. 
HÄGG, Tomas. The Ideal Greek Novel from a Biographical Perspective. In: KARLA, Grammatiki A. (Ed.) Fiction on the fringe: novelistic writing in the post-classical age. Leiden: Bril, 2009, p. 33-48.

HANSEN, William (Ed.). Ancient Greek Popular Literature. Bloomington and Indianapolis: Indiana University Press, 1998.

HOLZBERG, Niklas. Fable: Aesop. Life of Aesop. in Schmeling, G. (ed.) The novel in the ancient world. Boston: Brill Academic Publishers, 2003, pp. 633-9.

HOLZBERG, Niklas. The Anciente Novel. An Introduction. London and New York: Routledge, 1995.

HOLZBERG, Niklas (ed.). Der Ësop-Roman. Motivgeschichte und Erzählstruktur. Tübingen: Narr, 1992.

IPIRANGA JÚNIOR, Pedro. Romance apócrifo ou marginal. In: SIMPÓSIO DE ESTUDOS CLÁSSICOS DA USP, 3. São Paulo: Humanitas, 2009, p. 59-78.

IPIRANGA JÚNIOR, Pedro. Bios e hibridização: biografia cristã e pagã. Clássica, vol. 1, São Paulo, 2011, p. 90-101.

JOUANNO, Corinne. Novelistic Lives and Historical Biographies: The Life of Aesop and the Alexander Romance as Fringe Novels. In: KARLA, Grammatiki A. (Ed.) Fiction on the fringe: novelistic writing in the post-classical age. Leiden: Bril, 2009, p. 33-48.

KARLA, Grammatiki A. Fictional Biography Vis-à-vis Romance: Affinity and Diferentiation. In: KARLA, Grammatiki A. (Ed.) Fiction on the fringe: novelistic writing in the post-classical age. Leiden: Bril, 2009, p. 13-32.

KURKE, L. Aesopic conversations. Popular tradition, cultural dialogue and the invention of Greek prose. Princeton: Princeton University Press, 2011.

LUCIAN. Lucian with an English Translation. Translation by A. M. Harmon. Cambridge/Massachusetts/London: Harvard University Press, 1996 (v.I), 1988 (v.II), 1969 (v.III), 1992 (v. IV), 1996 (v. V), 1990 (v. VI). 
LUCIEN DE SAMOSATE. PHILOPSEUDĖS ET DE MORTE PEREGRINI. Introduction et commentaire de Jacques Schwartz (Ed.). Paris: Les Belles Lettres, 1963 (Publications de la Faculté des Lettres de l'Université de Strasbourg - Textes d'Ettude 12).

MOMIGLIANO, Arnaldo. La Naissance de la Biographie en Grèce Ancienne. Traduit de l'Anglais par Estelle Oudot, Strausbourg: Circé, 1991.

MORALES, Helen. Challenging some orthodoxies, 2009. In: KARLA, Grammatiki A. (Ed.) Fiction on the fringe: novelistic writing in the post-classical age. Leiden: Bril, 2009, p. 1-12.

NAGY, Gregory. The Best of the Achaeans. Baltimore : The Johns Hpkins Univesity Press, 1979.

PERRY, Edwin. The text tradition of the Greek Life of Aesop. in Transactions and Proceedings of the American Philological Association, v. 62, p. 198-244, 1933.

PHILOSTRATUS. The Life of Apollonius of Tyana. Ed. Christopher P. Jones, vol. 1 (Books I-IV) and 2 (Books VVIII). Cambridge (Mass.): Harvard University Press, 2005 (Loeb Classical Library no. 16 and no. 17).

PSEUDO CALÍSTENES. Vida y Hazañas de Alejandro de Macedônia. Traducción, prólogo ynotas de Carlos García Gual. Madrid: Editorial Gredos, 1988.

STONEMAN, Richard (Ed.). Il romanzo di Alessandro. Vol. I. Traduzione di Tristano Gargiulo. Fondazione Lorenzo Valla, Arnoldo Mondadori Editore, 2007.

Enviado em janeiro de 2014 Aprovado em abril de 2014. 